\title{
A fesztiválélmény megjelenése a közösségi médiában: a Sziget Fesztivál példája
}

\author{
Szerzők: Hinek Mátyás ${ }^{1}$ - Kulcsár Noémi²
}

A tanulmány célja, hogy bemutassa egy nagy hazai fesztivál által generált fogyasztói élmény dimenzióit. Az áttekintô fesztiválkörkép és a fesztiválok szerepének elméleti bemutatása után, affektív és kognitív értékdimenziók mentén megvizsgálja a Sziget Fesztivál, mint vezetô kulturális turisztikai termék látogatói számára élményt generáló tényezôket, különös tekintettel az affektív és a kognitív értékdimenziókra, amelyeket tanulmányunkban az élményteremtés pilléreinek nevezünk. A vizsgálatot a 2016-os Sziget Fesztiválon részt vett külföldi és hazai látogatók által a Facebookon elhelyezett vélemények kvalitatív tartalomelemzése alapján hajtottuk végre.

Kulcsszavak: fesztivál, fogyasztói érték, élményteremtés, kvalitatív tartalomelemzés.

\section{Bevezetés}

A fesztiválok kiválóan összekapcsolhatók a turizmussal, és pozitív hatásukat együttesen fejtik ki egy-egy település vagy térség gazdasági és társadalmi struktúrájára. Legszembetúnóbb a fesztiválok gazdasági szerepe. A fesztiválok erősítik a turisztikai desztinációk vonzerejét és pótlólagos programot kínálnak a más célból érkező turistáknak. Szerepük a nagyvárosok mellett különösen fontos lehet egy kistelepülés életében is, hiszen a fesztiválturisták a legtöbbet költő vendégek közé tartoznak, így jelentős bevételnövekedést jelenthetnek a települések költségvetésében. A helyi közösségek szempontjából szerepüket komplexen érdemes szemlélni. A fesztiválszervezés lehetőséget nyújt a kultúra regenerációjára, a helyi identitástudat erôsítésére és olyan képességek (szervezés, együttmúködés) elsajátítására, amelyek hasznosak a gazdasági élet területén (SULYOK-SZIVA 2009). Szerepük jelentős a helyi lakosok életminôségének növelésében is. Egyrészt, a fesztiválrendezést megelőzően településrendezésre, -szépítésre kerül sor, másrészt a kulturális és szórakoztató programok nemcsak a turisták, hanem a lakosság tetszését is elnyerik, hozzájárulnak tudásuk, toleranciájuk növeléséhez, hagyományaik és természeti értékeik megőrzéséhez, szemléletmódjuk formálásához

\footnotetext{
főiskolai tanár, Budapesti Metropolitan Egyetem, mhinek@metropolitan.hu

2 egyetemi docens, Budapesti Metropolitan Egyetem,

nkulcsar@metropolitan.hu
}

és társadalmi tőkéjük növeléséhez. A turisztikai programok helyi társadalomra gyakorolt pozitív hatása abban is megmutatkozik, hogy növelheti szúkebb környezetük erőforrásainak megbecsülését, büszkeségüket, illetve hozzájárulhat ahhoz, hogy a közösség a mindennapi élet során egy teljesebb, értékeit hasznosító helyen élhessen. Ez az életminőség-javulás azonban csak abban az esetben teljesedhet $\mathrm{ki}$, ha a desztináció turisztikai szolgáltatói és a fesztivál szervezói rendelkeznek a turisták számára értéket (élményt) teremtő erőforrásokkal és képességekkel (KULCSÁR 2016).

A rendszerváltás óta jelentősen átalakult a hazai fesztiválpiac, és egyre inkább érett piaci sajátosságokat mutat. A legkülönbözőbb célcsoportoknak biztosít színvonalas szórakozást, azonban leginkább a felnótt és az ifjú korosztály találhat magának megfelelőt, bár a gyermekfesztiválok aránya is folyamatosan nó (SZABÓ 2015). A külföldi vendégek részaránya 2011-től sajnos csökkenést mutat. Nem tudjuk pontosan, hogy ez a jelenség a belföldi turizmus növekedésével magyarázható-e vagy a külföldi vendégek számára lett kevésbé vonzó célpont Magyarország. A hazai turisztikai programokat felsorakoztató portál legnépszerúbb ajánlatai a különböző - elsősorban múvészeti és gasztronómiai - fesztivál megjelenések³ ${ }^{3}$ A 2019. évre ajánlott fesztiválok száma: 806 db, ebból gasztronómiai 297 $\mathrm{db}$, zenei $154 \mathrm{db}$, hagyományőrző $138 \mathrm{db}$, múvészeti/kulturális $149 \mathrm{db}$, sport $30 \mathrm{db}$, illetve további gyermek-, ifjúsági, családi, autós és egyéb fesztivál is szerepel a kínálatban. A regisztrált fesztivá-

${ }^{3}$ https://www.programturizmus.hu/kategoria-fesztival.html?f=30\&fs=d, Letöltve: 2017. március 11. 
lok megoszlását tekintve ${ }^{4}$ a legtöbb fesztivált Pest megyében rendezik (30\%), majd Veszprém megye (11\%) és Hajdú-Bihar megye (11\%) teljesítménye a leginkább kiemelkedő. SZABÓ JÁNOS ZOLTÁN (2015) fesztiválszakértő szerint kiemelkedő látogatószám emelkedés már nemigen várható. Az érett piaci sajátosságokat mutató magyar fesztiválpiacon a közeljövóben várhatóan már nem lesz fenntartható változatlan formában egy adott piaci pozíció, hiszen a látogatók megunják a változatlan formában megvalósított eseményeket. Kitörési pont lehet azonban a fesztiválok számára, ha újból érdekessé válnak, mint például a Sziget, a Balaton Sound és a Volt, amelyek évról évre folyamatosan újítanak, viszont ma már nem is annyira zeneileg, hanem inkább olyan attrakciók létrehozásával, mint például a kortárs építészek fából készült alkotásai. Ezekben az újításokban közös a fesztivál céljának és koncepciójának pontosabb azonosítása, és azok hangsúlyozása a fesztivál vizuális megjelenésében. Ezzel lehet különbözni az átlagtól, hiszen az átlagos fesztiválok jellemzően nem fogalmazzák meg pontosan a fő céljaikat, üzenetüket, illetve missziójukat.

Jelen tanulmány az említett három jelentôs és innovatív hazai fesztivál közül a Sziget Fesztivál látogatóinak 2016. évi véleményeit elemzi, és azonosítja a látogatók számára értéket jelentő tényezőket, értékdimenziókat.

\section{Szakirodalmi áttekintés}

A tanulmány a fesztiválok fogyasztóinak véleményét a fogyasztói érték kontextusában tárgyalja, és azonosítja a látogatók értékdimenzióit.

A fogyasztói érték koncepció több megközelítés alapján is vizsgálható: a termékközpontú értékesítési szemlélettől kezdve (SCHMITT 2003) a Kotlerféle marketing-koncepción (vö. KOTLER 2003) és a közelmúltban elótérbe kerülő CRM-en ${ }^{5}$ keresztül a fogyasztóiélmény-menedzsmentig (SCHULTZ 2003). Ezen újabb értelmezések szerint a fogyasztói érték nagyrészt szubjektív (HOFMEISTER et al. 2003), azaz a fogyasztó személyes véleményét tükrözi arról, hogy a kapott termék és szolgáltatás mennyiben felel meg az elvárásainak (PARASURAMAN et al. 1985). Annak érdekében, hogy ezt a fesztiválok megértsék és beépíthessék piaci stratégiájukba, nagy kihívásokkal kell szembenézniük.

Fogyasztói érték CHIKÁN és DEMETER (2004) szerint akkor képződik, ha a fogyasztó adott tranzakcióból származó haszna meghaladja a ka-

\footnotetext{
${ }^{4} \mathrm{http} / /$ www.fesztivalregisztracio.hu/index.php?modul=mar_regisztraltak, Letöltve: 2017. március 11.

${ }^{5}$ Customer Relationship Management, azaz vevői kapcsolatmenedzsment.
}

pott termék és szolgáltatáscsomag tulajdonlásának teljes költségét.

Az értéknek e szubjektív megfogalmazása igen átfogó, melyet a vevói értékdimenziók (value dimensions) fogalmán keresztül bonthatunk ki (GELEI 2006). Az értékdimenziók elemeire bontják a vevői értéket, és azt mutatják meg, hogy a kapott termék-, szolgáltatáscsomagnak melyek azok a fontosabb összetevői, dimenziói, amelyek jelentős mértékben járulnak hozzá a vevői érték növekedéséhez (WALTERS 2002). A tevékenységmenedzsment szakirodalma gyakorlatilag ezzel a meghatározással azonosan használja a versenyelőnyforrások fogalmát (CHIKÁN-DEMETER 2004), s többnyire konkrétan felsorolja azokat a legfontosabb tényezóket, amelyek révén a vevői érték megragadható, sôt növelhető, mindezek pedig az ár, minőség, rugalmasság, megbízhatóság és a központi termékhez kapcsolódó szolgáltatások.

Összességében a fogyasztói értéket a szakirodalom egydimenziós és többdimenziós értelemben is definiálja. A fogyasztói értéket egy dimenzió mentén megfogalmazó kutatók a tranzakciós értékre helyezik a hangsúlyt, ahol a fogyasztó a kapott termék, szolgáltatás és a megszerzéséért adott „áldozat” (például pénzmennyiség) közötti különbséget értékeli.

Más szerzők a fogyasztói értéket többdimenziós észlelt fogyasztói értékként sokszor "komplexnek" (LAPIERRE 2000), „többtényezősnek” (BABIN et al. 1994), "dinamikusnak" (WOODRUFF 1997, PARASURAMAN-GREWAL 2000) vagy „szubjektívnek" (ZEITHAML 1988) definiálják. A kétféle típusú fogyasztói érték értelmezés az 1. táblázatban részletezetteknek megfelelően tér el egymástól.

A fentiek értelmében egyre inkább a fogyasztó szubjektív észlelése, tapasztalata a meghatározó a vásárolt termék, szolgáltatás végső értékelésekor. A fogyasztói elégedettségben fontos szerepet töltenek be az elózetes várakozások és az ezekhez viszonyított valós észlelés. Az a látogató, akinek várakozásait meghaladja a vásárolt termék, illetve szolgáltatás hasznossága, hajlamos lojálisan viselkedni a fesztivállal szemben, míg az, amelyik csalódott, könnyen elcsábítható. Sokszor azonban az elégedettség nem elég a tartós vevőkapcsolathoz, hiszen a várakozásokon felül kapott érték hangsúlyosabb lehet (CHIKÁN-DEMETER 2004).

Következtetésként megállapítható, hogy az eddigi értekezésekben a fogyasztói érték kutatások három területe jelent meg:

- a termékválasztást és vásárlási szándékot, illetve az újravásárlást ösztönzó értékek kutatása; 
Lektorált tanulmányok

- a minőség - érték - elégedettség - lojalitás öszszefüggéseinek vizsgálata;

- a gazdasági-pszichológiai, azaz kognitív-affektív fogyasztói értékdimenziók kapcsolata.

A fogyasztói érték megközelítéseinek

1. táblázat összehasonlítása

\begin{tabular}{|l|l|}
\hline $\begin{array}{l}\text { Egydimenziós fogyasztói } \\
\text { érték }\end{array}$ & \multicolumn{1}{|c|}{$\begin{array}{c}\text { Többdimenziós } \\
\text { fogyasztói érték }\end{array}$} \\
\hline $\begin{array}{l}\text { alapja: } \\
\text { gazdálkodástudomány, } \\
\text { kognitív pszichologia }\end{array}$ & $\begin{array}{l}\text { alapja: fogyasztói } \\
\text { magatartás elmélet }\end{array}$ \\
\hline $\begin{array}{l}\text { haszonelvú és gazdasági } \\
\text { koncepció }\end{array}$ & magatartás pszichológia \\
\hline kognitív megközelítés & $\begin{array}{l}\text { kognitív-affektív } \\
\text { megközelítés }\end{array}$ \\
\hline egyszerúség & komplexitás \\
\hline fókusz: hogyan értékeljünk & $\begin{array}{l}\text { fókusz: hogyan növelhetố a } \\
\text { fogyasztói érték }\end{array}$ \\
\hline $\begin{array}{l}\text { konszenzushiány } \\
\text { az értékelözmények } \\
\text { tekintetében }\end{array}$ & $\begin{array}{l}\text { konszenzushiány az } \\
\text { értékkomponensek } \\
\text { tekintetében }\end{array}$ \\
\hline $\begin{array}{l}\text { tisztázatlan kapcsolatok az } \\
\text { értékelözmények között }\end{array}$ & $\begin{array}{l}\text { tisztázatlan kapcsolatok az } \\
\text { értékkomponensek között }\end{array}$ \\
\hline $\begin{array}{l}\text { az érték közvetlen módon } \\
\text { megfigyelhetố }\end{array}$ & $\begin{array}{l}\text { az érték csak közvetve, a } \\
\text { komponensein keresztül } \\
\text { figyelhetố meg }\end{array}$ \\
\hline $\begin{array}{l}\text { gyakori szakirodalmi } \\
\text { megjelenés }\end{array}$ & $\begin{array}{l}\text { ritka szakirodalmi } \\
\text { megjelenés }\end{array}$ \\
\hline
\end{tabular}

Forrás: SÁNCHEZ-FERNÁNDEZ-INIESTA-BONILLO (2007:442)

A fesztiválturizmusban megjelenő fogyasztói értékdimenziók feltárásához releváns megközelítés a multidimenzionalitás vizsgálata. A fogyasztói érték összetevói között:

- egyrészt megjelenhetnek a racionális (kognitív) döntésból adódó és funkcionalitásra összpontosító dimenziók (például az egyes szolgáltatáselemek ára és minősége),

- másrészt a fogyasztó termékkel kapcsolatos megítélésére ható affektív dimenziók (például a hangulat, az érzések, a kapcsolatok, az élmények).

Az élmény értékdimenzió tágabban véve is értelmezhető, előfordulhat, hogy az affektív dimenziók összességét foglalja magába. De YUAN és WU (2008) szerint akár a teljes fogyasztói értékítélet is alapulhat magán a komplex élményen.

\section{A vizsgálat módszertana}

A vizsgálatot Magyarország legnagyobb fesztiválja, a Sziget Fesztivál kapcsán végzetük el.
Feladatunknak azt tekintettük, hogy látogatói élménydimenziókat azonosítsunk, beleértve az affektív (hangulat, érzések) és kognitív (tudatosan feldolgozott és értékelt élmények) vonatkozásokat is.

$\mathrm{Az}$ adatgyújtésre a Sziget Festival Official Facebook oldalát ${ }^{6}$ használtuk, melyen belül a "Vélemények" rovatban megjelenó szöveges véleményeket, azaz Facebook bejegyzéseket és az egyes posztokhoz tartozó hozzászólásokat dolgoztuk fel. A feldolgozás idôszakát egy naptári évben határoztuk meg - 2016. január 1. és 2016. december 31. között -, mely időintervallumban az összes megjelent véleményt és hozzászólást átnéztük.

A vizsgált időszakban összesen 925 posztot és hozzászólást találtunk. Igyekeztünk az egyes posztokhoz tartozó összes hozzászólást összegyújteni, ám a Facebook nem mindegyik bejegyzést mutatja meg alapnézetben, így ezek megnyitásához esetenként további kattintásokra volt szükség, ezért nem vagyunk teljesen biztosak abban, hogy az összes hozzászólást maradéktalanul sikerült összegyújtenünk.

A bejegyzéseket először Excelbe másoltuk át, majd előszúrést végeztünk a témánk szempontjából releváns tartalom kiválogatására. Nem tekintettük relevánsnak azokat a posztokat és hozzászólásokat, amelyeket nem a fesztivál látogatói írtak, hanem például a helyiek, akik jellemzően a fesztivál által okozott zajterhelés miatt panaszkodtak. Hasonlóképpen nem tekintettük relevánsnak a szervezők hozzászólásait sem, amelyek jellemzően látogatói kérdésekre adott válaszok voltak. Nem voltak relevánsak azok a bejegyzések sem, amelyek tartalma látogatók közötti információcsere volt (például mikor kezdődnek a programok vagy milyen jármúvel lehet a helyszínre utazni). Csak azokat a posztokat és hozzászólásokat vizsgáltuk, amelyeket a fesztivál látogatói írtak, és tartalmuk egyértelmúen a fesztivállal volt kapcsolatos. Ezek sok esetben csak néhány szavas tetszésnyilvánítások (például „Amazing!” - Csodálatos!), más esetekben hosszabb értékelések a fesztivál által nyújtott különböző szolgáltatásokkal kapcsolatban (például beléptetés, kemping, büfék, kiegészítő programok). Találtunk több olyan bejegyzést is, amely megpróbálta megfogalmazni, hogy a szerzóje mivel volt elégedett vagy elégedetlen, hogy milyen jellegú élményt szerzett a Sziget Fesztiválon. Vizsgálatunk szempontjából ezek a bejegyzések voltak a leghasznosabbak.

$\mathrm{Az}$ induló több mint kilencszáz poszt és hozzászólás közel kétharmadát töröltüuk az adatbázisból. Összesen 316 bejegyzést tartottunk meg, amelyekhez hozzárendeltük a szerzők nemzeti-

\footnotetext{
$\overline{{ }^{6} \text { https://www.facebook.com/SzigetFestival/ }}$
} 
ségét, a bejegyzés dátumát, valamint a fesztivál értékelését, amelyet a hozzászólók 1-5-ös skálán adhattak meg.

A kiválogatott bejegyzéseket 247 különbözó fesztivállátogató írta. Egy látogató több bejegyzést is írhatott, például úgy, hogy egy poszt szerzője a hozzászólásokra válaszolva maga is aktívan kivette részét a kibontakozó diskurzusban. Az elemzett bejegyzések több mint nyolcvan százaléka 2016 augusztusában íródott, többségében a fesztivál napjaiban vagy közvetlenül utána.

A vizsgált bejegyzések ötvennyolc százaléka íródott idegen nyelven, jórészt angolul, de elófordult francia, spanyol, portugál, orosz, koreai, kínai és egyéb nyelvú bejegyzés is. A bejegyzésekhez tartozó nevek vizsgálata alapján 152 külföldi és 95 magyar fesztivállátogatót azonosítottunk. A nevek és a Facebook profilok alapján a hozzászólásokat írók neme, kora és egyéb demográfiai jellemzői (beleérve a konkrét származási országot is) nem mindig volt azonosítható, így ezt az elemzés során nem használtuk fel. Az első körös kódolás leíró kódolással történt, ennek során az egyes szövegrészeket azok tartalma alapján kódoltuk NVivo segítségével (SALDANA 2015). A 316 bejegyzésben összesen 536 szövegrészhez rendeltünk kódokat, egy-egy szakaszhoz többszörösen is, ha a témák nem váltak szét egyértelmúen.

Az első körös kódolás során több mint hetven kiinduló kódot generáltunk, amelyeket több lépésben szûrtünk és tisztítottunk. Egyes kiinduló kódokat átfogalmaztunk és pontosítottunk, illetve töröltünk. Az ugyanolyan, vagy nagyon hasonló tartalmú kódokat összevontuk, így az első körös kódolás lezárását követően összesen 54 különböző kiinduló kódunk maradt.

A kiinduló kódokat a második körben a kódok által azonosított fóbb témák mentén csoportosítottuk. Az így kialakult kétszintú struktúrában összefoglaló, illetve résztémák rajzolódtak ki. A további elemzés alapvetóen kvalitatív jellegú volt, de a hozzászólások egyes jellemzői (például nemzetiség, szentiment) alapján vegyes módszertant is alkalmaztunk (NEULINGER 2016).

\section{A Sziget Fesztivál Official Facebook oldalán a Vélemények rovat látogatói hozzászólásai alapján kirajzolódó témák és kapcsolataik}

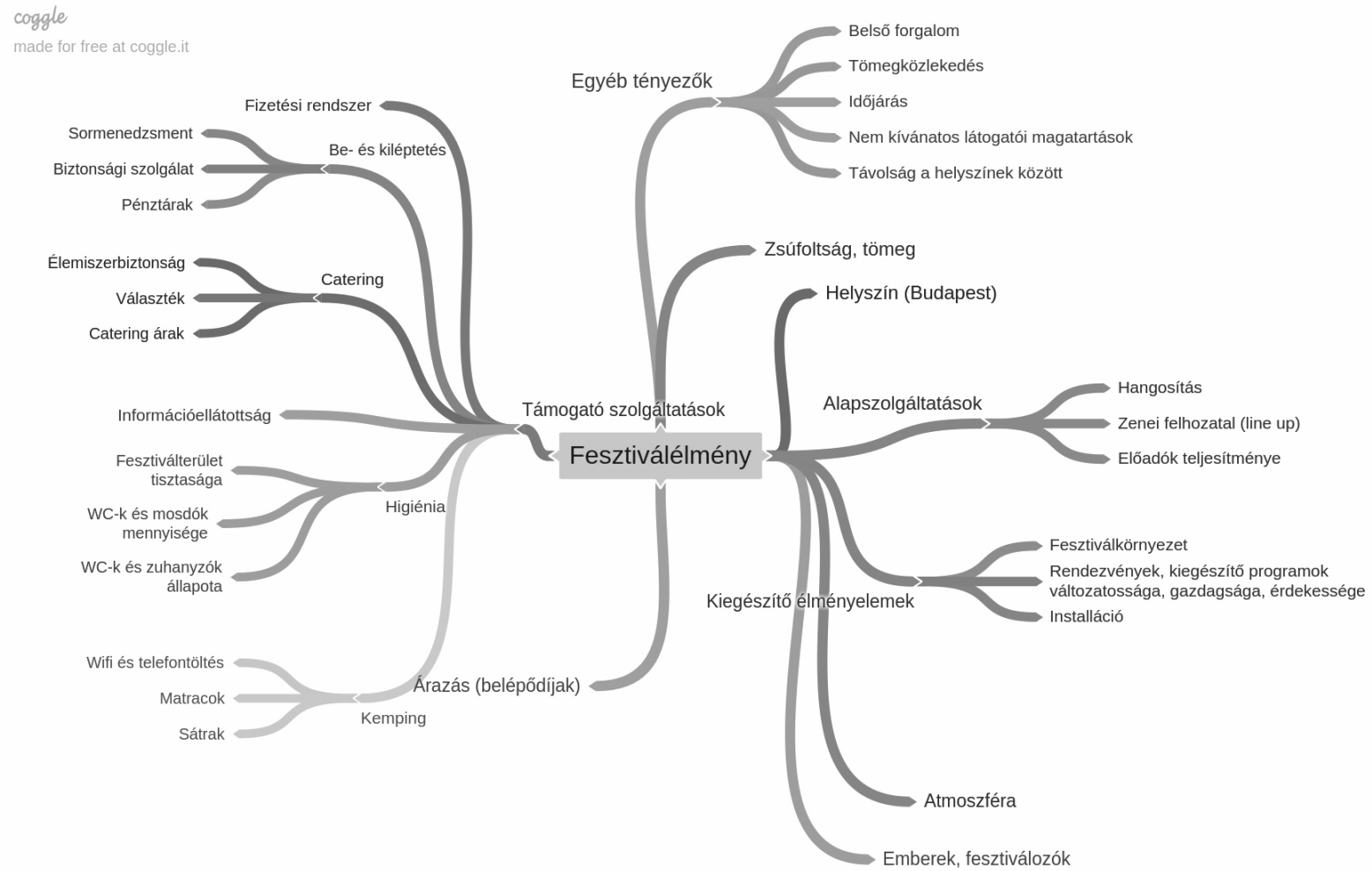

Forrás: saját szerkesztés a Sziget Festival Official Facebook oldalán megjelenő szöveges értékelések alapján 


\section{Eredmények}

\subsection{A FESZTIVÁLÉLMÉNYT MEGHATÁROZÓ TÉNYEZŐK}

A kódokat, valamint a kódok csoportosításával kirajzolódó átfogó- és résztémákat gondolattérképre vittük fel. A térkép a véleményekben megjelenó meghatározó élménytényezőket, valamint kiegészítő szolgáltatások és egyéb tényezők révén a látogatói élmény további elemeit rajzolja ki. A térképen jól látszik, hogy a fesztiválélményt a fesztivál alap-, támogató és kiegészítő szolgáltatásai mellett számos egyéb tényező befolyásolja a zsúfoltságtól az időjárásig (1. ábra).

A bejegyzések alapján a fesztivál alapszolgáltatásai közül egyértelmúen a line-up (zenei program) a legfontosabb. A line-uppal kapcsolatos véleményeket pozitív és negatív kódokkal is elláttuk a bejegyzés szentimentjétől függően (például kiváló line-up /+/, nem megfelelő line-up /-/, remek előadók koncertek /+/, nem megfelelő előadók, gyenge koncertek /-/). A hozzászólások alapján a line-up az élmény meghatározó tényezője volt, ahogy az egyik hozzászóló megjegyezte „an endless variety of absolutely incredible artists" (hihetetlenül jó előadók végtelen változatossága). Ugyanakkor néhány hozzászóló negatív kontextusban értékelte a zenei programot (,but lines were disappointing" - a fellépők csalódást okoztak), bár a negatív vélemények lényegesen ritkábbak voltak, mint a pozitívak. Volt olyan hozzászóló, aki inkább elnézó jelleggel fogalmazott meg kritikát: „Hope for a better line-up next year." (Remélem, hogy a következő évben jobb lesz a felhozatal.)

Az egyes előadók teljesítményének megítélése változatos volt. Túlsúlyban voltak a Rihanna 0 . napi koncertjével kapcsolatos bejegyzések, szinte csak negatív felhanggal. Különösen a magyar, napijegyes látogatók nehezményezték, hogy a fellépés fél órát csúszott, miközben hatalmas volt a tömeg, és hosszú sorok alakultak ki a pénztáraknál. Az elemzett magyar hozzászólások közel tizennégy százaléka foglalkozott ezzel a koncerttel, szemben a külföldi véleményekkel, ahol mindössze a bejegyzések töredékében jelent meg a Rihanna koncert. A fellépéssel elégedetlen magyar posztolók közel kétharmada alacsony, 1-es vagy 2-es értékelést adott az ötfokozatú skálán, miközben a fesztivál általános megítélése 4,5 feletti a Facebook-on, ami jól jelzi, hogy a kiemelt programok a fesztiválélményt alapvetően meghatározó tényezők. Ezzel szemben a véleményírók pozitívan emlékeztek meg a Muse, az Asus, a Manu Chao, a Sum 41, a The Neighbourhood, Parov Stelar és Afrojack teljesítményéról, amelyek szin- tén head-linerek, azaz kiemelt előadók voltak a 2016-os Sziget Fesztiválon.

Rihanna koncertjén teltház volt, 90 ezer látogatóval. A programhoz kapcsolódó zsúfoltság, tömeg, valamint egyes helyzeteket nem mindig jól kezelő fesztiválszemélyzet (fóként a beléptetéseknél közremúködő biztonsági emberek) negatív kontextusban kerültek elő a hozzászólásokban. Számos kritika fogalmazódott meg a beléptetési rendszerrel kapcsolatban: „Viszont a bejutás és kijutás a szigetrôl kaotikus és felháborító volt!!!”, „Mi is inkább hazamentünk 2 óra sorban állás után. A szervezők ezt nagyon elcseszték!". Ugyanakkor volt, aki pozitív élményekről számolt be, de ez volt a ritkább: „A bejutásnál nem voltak gondok, várakozni se kellett sokat!".

Az alapszolgáltatásokat kiegészító élményelemeknek tekinthetőek a különböző kísérőprogramok (cirkuszsátor, filmprogram, az eseti rendezvények, múvészeti programok stb.), valamint a fesztivál fizikai környezete (például az installációk). Ezek az elemek a hozzászólásokban pozitív aspektusban jelentek meg. Ahogy az egyik látogató megfogalmazta: "Amazing line-up with not only concerts, but also circus shows, attractions all over the island (art zone, I Ching Labyrinth, or Hungarikum village) and nonstop parties in bars and Island's streets. Shout out to the Magic Mirror's Berlinesque Cabaret (what a breath-taking show!), Rossmann's Bubble parties and cheap saviour of our hungry guts Aldi. Impossible to catch up with everything but expect to be entertained every second you are up!" (Csodálatos line-up, nemcsak koncertek, hanem cirkuszi show-k, látnivalók az egész szigeten (múvészeti zóna, Ji Csing Labirintus vagy a Hungarikum falu), nonstop partik a bárokban, valamint a Sziget utcáin. Ki kell emelni a Magic Mirror Berlinesque kabaréját (lélegzetelállító show!), a Rossmann habpartijait, és éhes hasunk olcsó megmentőjét, az Aldit. Lehetetlen mindent kipróbálni, de számíthatsz arra, hogy minden másodpercben szórakoztatnak!). A hozzászólások alapján a kiegészítő programok jelentősen növelték a látogatók élményét, bár egy-egy hozzászólásban kiemelték azt is, hogy egyes sátrak zsúfoltak és levegőtlenek voltak.

A fesztivál higiéniai helyzete (WC-k, zuhanyzók állapota, elérhetősége), majdnem kizárólag negatív hozzászólások formájában jelent meg, különösen a külföldi véleményezők körében. A külföldiek által írt hozzászólások több mint tíz százaléka foglalkozott a témával (szemben a magyar hozzászólások három százalékával). Ahogy az egyik véleményíró megfogalmazta: „Toilets were ultra grim” (a WC-k különösen undorítók voltak), illetve a csapok, mosdók mennyiségével és állapotával is adódtak 
problémák, előfordult, hogy sorok alakultak ki a szaniteregységek előtt. Volt olyan külföldi hozzászóló, aki azt emelte ki, hogy a fesztiválon nem lehetett csak úgy letelepedni a fúbe sem, mert azt kockáztatta az ember, hogy beleül valamibe.

A tisztaság is több kritikát kapott. Találtunk olyan véleményt, amely kiemelte, hogy a nyugat-európai fesztiválokon jobb a szeméthelyzet. A fesztivál utáni időszakban is érkezett olyan hozzászólás, amely azt nehezményezte, hogy hetekkel a rendezvény után még mindig szemetes az Óbudaisziget, és ez a szervezô hibája.

Az alapvető problémákhoz szorosan kapcsolódva jelent meg a vélemények között a kempinggel kapcsolatos problémahalmaz. Különösen a fesztivál területén megvásárolható sátrak és matracok magas ára és alkalmatlansága „verte ki a biztosítékot" a szolgáltatást igénybe vett fesztiválozók körében. A szervezők által forgalmazott sátorban nem fért el két ember, előfordult, hogy a zipzárak fülei már az első használatkor leszakadtak, a sátrak beáztak, a Polifoam matracok kicsik és vékonyak voltak. A szolgáltatás árazásával és minőségével kapcsolatban gyakran leírt vélemény a "rip off" (lehúzás) volt.

A hozzászólások megoszlása alapján arra számítottunk, hogy a kemping és higiénia problémái összekapcsolódnak, különösen a külföldiek körében (mivel nagyobb eséllyel nekik volt szállásuk a fesztivál területén), ezt azonban a hozzászólások elemzése nem igazolta. A kemping és a higiénia mindössze két véleményben jelent meg egyszerre.

A catering (büfék, ételbárok, pizzériák, sörözők stb.) választékának megítélése vegyes volt, nagyjából hasonló arányban kódoltunk negatív és pozitív véleményeket. A hozzászólók közül többen jelezték, hogy ételmérgezést kaptak a Sziget Fesztiválon. Az egyik poszt és a hozzá érkezett hozzászólás-füzér arról tudósított, hogy több külföldi megbetegedett, ami miatt az érintetteknek idő előtt haza kellett utazniuk. (Az ezzel kapcsolatos bejegyzések a fesztivál zárását követő napokban Reddit-en is megjelentek.)

A hozzászólók ugyanakkor méltatták a szervezettséget, többször is megfogalmazták, hogy a versenytársaival összehasonlítva a Sziget Fesztivál jobban szervezett: „Having experienced the biggest UK festivals this is much more organised and ten times better in general (...)" (Ismerve a legnagyobb brit fesztiválokat, ez sokkal szervezettebb és összességében tízszer jobb (...).

Az egyéb, fesztivállal kapcsolatos tényezők között jelent meg a helyszin (,the surrounding city of Budapest is perfect" - Budapest környező városa tökéletes), a megközelíthetôség („Egy Sziget buszjárat beszervezése enyhítene a Hév tömöttségén”), az információellátottság („A Sziget Viber nagyon cuki! Olyan, mintha az anyukám lenne!”, „most of people that were there to work don't know anything of English" - az ott dolgozó emberek többsége semmit nem tudott angolul), az idôjárás (,great weather" - nagyszerú időjárás) és a készpénz nélküli fizetési rendszer (fesztiválkártya) („Cashless system is deadly" - A készpénz nélküli rendszer halálos).

Az árakkal kapcsolatban negatív vélemények elsôsorban a fesztiválon vásárolható ételek és italok, valamint sátrak és matracok árai kapcsán jelentek meg, különösen, hogy ezek minóségét nem mindig érezték megfelelőnek a véleményeket írók. Ahogy az egyik látogató írta: „Drink prices are regulated by management and alright, but some food is just terribly overpriced comparing to the Hungarian standard (in most cases triple or four times more) and unfortunately from my experience of such a bad quality, that you actually don't wanna eat it at all..." (Az italárakat a menedzsment jól szabályozza, de egyes ételek a magyar átlaghoz képest szörnyen túlárazottak (a legtöbb esetben háromszor vagy négyszer többe kerülnek), és sajnos a tapasztalataim szerint olyan rossz minóségúek, hogy egyáltalán nem akarsz enni.). A fesztivál belépójegyeinek árait ellenben nem találták drágának egyes külföldi hozzászólók, különösen a nyugat-európai árakkal összehasonlítva.

A vizsgálatunk fókuszát képező fesztiválélmény legmarkánsabban az elégedettség kifejezésében jelent meg. A Sziget Festival Official Facebook oldalon megjelenő véleményeket a rövid tetszésnyilvánítások uralták, a fesztiválozók gyakran csak egyetlen szóval vagy rövid mondattal írták le az élményüket, például:

• „Epic!!” (Hatalmas!!)

- "Hihetetlen! <3"

• „Amazing!!! ...to becontinued!!!!” (Elképesztő!!! ...folytatása következik!!!)

• „Just wonderful week in Sziget !!" (Egy csodálatos hét a Szigeten!)

• „Best festival ever!!” (A legjobb fesztivál!!)

- „Brilliant, brilliant, brilliant!” (Brilliáns, brilliáns, brilliáns!)

A valamivel hosszabban megfogalmazott tetszésnyilvánításokat jól jellemzik az alábbi kiragadott példák:

- "One of the most incredible experience of my life!” (Életem egyik leghihetetlenebb élménye!)

- „Best music festival in the world! Always an amazing line up and atmosphere... Can't wait to go back." (A világ legjobb zenei fesztiválja! Mindig elképesztô a line-up és az atmoszféra... Alig várom, hogy visszatérjek.) 
Lektorált tanulmányok

- "The best Festival of the whole World! Amazing People \& a Place of real Freedom!!" (A világ legjobb fesztiválja! Csodálatos emberek és a valódi szabadság szigete!!)

- Az élménnyel kapcsolatban egy találó összefoglalás az egyik fesztiválozó részérőli „I loved so much my experience in Sziget!" (Annyira szerettem az élményemet a Szigeten!).

Az élmény fontos eleme volt a közönség, a fesztivállátogatók. Többen kiemelték a jó társaságot, amely a Sziget Fesztiválra jellemző. „The people are all legends" (Minden ember legenda), írta az egyik külföldi fesztivállátogató, míg egy magyar hozzászóló úgy fogalmazott, hogy "hihetetlenül barátságos emberek". Megint más vélemény szerint: „(...) the festival was amazing full of happy people from all over the world. A "must see" definitely!" (A fesztivál csodálatos volt, a világ minden tájáról származó boldog emberekkel. Egyértelmúen „látni kell”!).

Ugyanakkor nem minden hozzászólásban volt pozitív a látogatók megítélése. Több bejegyzés foglalkozott a fesztiválozók nem megfeleló viselkedésével, így például egy magyar véleményíró szerint: „Részeg emberek tolonganak, egymásra egyáltalán nincsenek tekintettel, teljesen lealjasodva közben a nagy béke és szeretet jegyében repülnek a nagy szavak.". A hozzászólások között elókerültek egyéb érzékelt problémák is (például dohányzás, füvezés a tömegben).

A fesztivál atmoszféráját, hangulatát is kiemelték több hozzászólásban: „The general atmosphere was still great!" (Az általános hangulat egyébként nagyszerú volt!), "A delightful experience and atmosphere” (Elbúvölő élmény és hangulat), „Good fun" (Jó móka).

A hozzászólásokban megfogalmazott visszatérési szándék (miszerint a jövôben is látogató lesz a Sziget Fesztiválon) összefüggött az elégedettséggel. $\mathrm{Az}$ általunk kódolt pozitív élményt megfogalmazó hozzászólások ötödében jelent meg a jövőbeni visszatérési hajlandóság, illetve fordítva, a jövőbeni visszatérési hajlandóságot kinyilvánító hozzászólások fele pozitív élményrôl is beszámolt, azaz az előzetes várakozásainknak megfelelően egyértelmú kapcsolat mutatható ki az élmény és az újralátogatási hajlandóság között.

\subsection{A FESZTIVÁLLÁTOGATÓK AFFEKTÍV ÉS KOGNITÍV ÉLMÉNYE}

A fesztiválozók véleményének elemzése arra mutat rá, hogy sok látogató kiemelkedő élménnyel távozott a fesztiválról, amit sokszor túlfútött, érzelmekkel teli véleményekben osztottak meg. Az egyik olasz látogató lényegében egy irodalmi igé- nyességú rövid novellát írt arról, hogy mennyire szürkék a hétköznapjai a Sziget Fesztivál nélkül, és mennyire várja, hogy újra ott lehessen - így a jegyek elóértékesítésének megkezdésekor azonnal megrendelte a hetijegyét a következő fesztiválra.

A vélemények elemzése alapján jól megragadható, hogy a fesztivál komplex élményt (fogyasztói értéket) nyújt, és a szakirodalommal összhangban ezt az élményt kognitív és affektív elemek alkotják. A vélemények alapján az a következtetés vonható le, hogy minél erősebb a látogató érzelmi érintettsége, minél jobban elragadja a Sziget Fesztivál különleges atmoszférája, azaz minél mélyebben bevonódik, annál intenzívebb az általa megélt élmény. Eközben azok az inkább kognitív tényezők, amelyek minősége akár mérhetô is lenne (például menyire tiszták a mellékhelyiségek, mennyire szakszerú a személyzet, milyen drága a sör, beázik-e a méregdrágán megvásárolt sátor), nem feltétlenül ellenpontozzák a bevonódással létrejött élményt. Másképp fogalmazva: a Sziget Fesztivál vagy „elvarázsolja” a látogatót, és ebben az esetben a kiegészítő szolgáltatáselemek kevésbé lesznek fontosak, illetve ezekre is pozitívabban tekint a látogató, vagy a fesztivál nem érinti meg mélyebben, így a technikai jellegú tényezők (fellépók, tisztaság, árak, szolgáltatásminőség) felértékelődnek, és jelentósebb súllyal határozzák meg a fesztiválélményt (2. táblázat).

2. táblázat

\section{A fogyasztói élmény pillérei a Sziget Fesztiválon}

\begin{tabular}{|c|c|}
\hline $\begin{array}{c}\text { Inkább affektív } \\
\text { tényezók }\end{array}$ & $\begin{array}{c}\text { Inkább kognitív } \\
\text { tényezők }\end{array}$ \\
\hline Hangulat & Line-up, headlinerek \\
\hline Az „élō atmoszféra” & Árak \\
\hline $\begin{array}{r}A_{\text {„szabadság szigete" }} \\
\text { érzés }\end{array}$ & Személyzet \\
\hline Nagyszerü emberek & Catering \\
\hline Kiváló koncertek (show) & Kiegészítô szolgáltatások \\
\hline $\begin{array}{r}\text { Kiszakadás a valós } \\
\text { világból }\end{array}$ & Tisztaság, higiénia \\
\hline Helyszín & Látogatómenedzsment \\
\hline$s t b$ & $s t b$. \\
\hline $\begin{array}{l}\text { Föként az érzelmekre } \\
\text { ható, mélyebben } \\
\text { átélt élmények, } \\
\text { amelyek tudatosan is } \\
\text { értékelhetőek. } \\
\text { Az átélés miatt az } \\
\text { affektív tényezők } \\
\text { erôsebbek lehetnek, } \\
\text { elmerülést, azonosulást } \\
\text { kínálnak. }\end{array}$ & $\begin{array}{c}\text { Tudatosan megélhetó } \\
\text { és értékelhetô tényezók, } \\
\text { de affektív reakciót is } \\
\text { kiválthatnak. }\end{array}$ \\
\hline
\end{tabular}

Forrás: saját szerkesztés 
Az élménypillérekben jelölt affektív és kognitív tényezők nem válnak szét élesen, illetve az affektív-kognitív felosztás nem kizárólagos. Amennyiben az affektív élmény lényegét meg tudja fogalmazni a látogató, akkor az eredetileg érzelmi síkon megélt élmény tudatos, kognitívan feldolgozott élménnyé válik (AHN-PICARD 2014). Például egy kanadai fesztiválozó konkrétan és komplexen le tudta írni annak az élménynek a lényegét, amit a Sziget Fesztivál nyújt a látogatói számára. Ennek nyomán az átélt, eredetileg elsôsorban affektív élmény kognitívvá, tudatosan megragadhatóvá vált: „Everyone is relaxed and feels good there, the atmosphere is unique where everyone enjoys every moment of it, and every moment of it together. This is what makes it the Island of Freedom. This festival is mostly about the living atmosphere and the people creating it, and all the attractions and surrounding that makes the time spent there awesome (...)" (Mindenki ellazult és jól érzi magát, az atmoszféra egyedülálló, mindenki élvezi minden pillanatát és az együttlét minden pillanatát. Ez az, ami a Szabadság Szigetévé teszi. Ez a fesztivál főként az eleven atmoszféráról, az azt létrehozó emberekrôl, valamint minden olyan attrakcióról és környezetéról szól, amelyek az eltöltött időt gyönyörúvé teszik (...), "This is a festival is not only about the headliners. It's for spontaneous, free spirited and fun people who enjoy randomness, music, art, fun, party and want to feel free and forget the real world for a few days." (Ez a fesztivál, nem csak a head-linerekról szól. Ez a spontán, a szabad szellemú és vidám emberek fesztiválja, akik élvezik a véletlenszerúséget, a zenét, a múvészetet, a szórakozást, a bulit, és néhány napig szabadnak akarják érezni magukat, elfelejtve a való világot.).

$\mathrm{Az}$ élményszerzésnek van még egy fontos tulajdonsága, amelyet a szakirodalom „közös élményteremtésnek" nevez (lásd például BINKHORSTDENKER 2009). Ez a fesztivállátogatók esetében azt jelenti, hogy nemcsak passzívan megélik az élményt, hanem részt vesznek az élmény létrehozásában is. A fesztivál atmoszférája ennek a közös élményteremtésnek az eredménye.

A fesztivál sikerességét hosszú távon az határozza meg, hogy milyen élményt tud nyújtani. Mivel az élmény rengeteg komplex, egymással is interakcióban álló elembő́l tevôdik össze, a szervezőknek olyan tényezókre is figyelniük kell, amelyeket nem tudnak közvetlenül befolyásolni. Kutatásunk - és a szervezők sok éves tapasztalata - rámutat arra, hogy egy könnyúzenei fesztivál legfontosabb élményeleme (egyben alapszolgáltatása) a line-up, azaz a zenei program. Ez azonban önmagában nem elegendô, számos további tényezőt - köztük olyanokat is, amelyekre alig, vagy egyáltalán nincs befolyása a szervezóknek - kell menedzselni ahhoz, hogy a fesztivál valóban sikeres legyen.

\section{5. Összefoglalás}

Tanulmányunkban bemutattuk a fesztiválok turizmusban játszott szerepét, továbbá a Facebookon fellelhetô látogatói vélemények elemzésével megvizsgáltuk, hogy melyek voltak a fesztiválozók számára élményt generáló tényezők a 2016-os Sziget Fesztiválon. Vizsgálatunk alapján a látogatói élmény komplex, kognitív és affektív dimenziókban egyaránt értékelhető, amelyek között lehetséges az átjárás: az affektív élmény tudatosan értelmezhetó, ezzel kognitívvá is válik, míg a kognitív élményeknek is lehet affektív dimenziója.

$\mathrm{Az}$, hogy mi, és mennyiben jelent élményt, függ az egyes látogatóktól is, akik a különböző tényezóket eltéróen értékelhetik. A Sziget Fesztivál példáján azt láttuk, hogy a zenei program elsődlegessége mellett a szolgáltatás további elemei is fontosak a látogatói élmény szempontjából, de az egyes elemek súlya eltéró, és ezek jelentősége látogatóról-látogatóra változik. A véleményeket olvasva úgy túnik, hogy az egyes elemek egymásra is hatnak, azaz a látogató szempontjából interakció van közöttük. Valamely élménytényező(k) kiemelkedő teljesítménye tompíthatja a más tényezőkkel kapcsolatos negatív élményt, és fordítva, a negatív benyomások, akár a kiegészító szolgáltatások körében, elronthatják a teljes fesztiválélményt. Ezen felül az élményhez maguk a fesztivállátogatók is hozzájárulnak (közös élményteremtés).

A fesztiválmenedzsmentek feladata nem egyszerú. Nagyon sok, egymással kölcsönhatásban álló tényezôt kell sikeresen koordinálni ahhoz, hogy a látogató pozitív élményekkel távozzon, ám a szervezóknek ezek egy részére nincs, vagy csak közvetetten van befolyása. Az élmény határozza meg az újralátogatási hajlandóságot. Ha az élmény, a bevonódás mélyebb, valószínúbb a viszszatérés.

A Facebookon olvasható vélemények alapján a Sziget Fesztivál különleges és maradandó élményt nyújt, így a látogatók visszatérési hajlandósága kiemelkedô. Sikere elsősorban ennek köszönhető.

\section{Felhasznált irodalom}

AHN, H. - PICARD, R.W. (2014): Measuring Affective-Cognitive Experience and Predicting Market Success. IEEE Transactions on Affective Computing. 5(2). pp. 173-186.

BABIN, B. J. - DARDEN, W. R. - GRIFFIN, M. (1994): Work and/or Fun: Measuring Hedonic 
and Utilitarian Shopping. Journal of Consumer Research. 20(4). pp. 644-656.

BINKHORST, E. - DEKKER, T. D. (2009): Agenda for Co-Creation Tourism Experience Research. Journal of Hospitality Marketing \& Management. 18(2-3). pp. 311-327.

CHIKÁN A. - DEMETER K. (2004): Értékteremtó folyamatok menedzsmentje. Aula Kiadó, Budapest.

GELEI A. (2006): Beszállító-típusok és azok alapvető kompetenciái a hazai autóipari ellátási láncban. Doktori $(\mathrm{PhD})$ értekezés. Budapesti Corvinus Egyetem, Gazdálkodástani Doktori Iskola, Budapest.

HOFMEISTER T. Á. - SIMON J. - SAJTOS L. (2003): Fogyasztói elégedettség. Alinea Kiadó, Budapest.

KOTLER, P. (2003): Marketing Management. 11th Ed. New Jersey, USA: Pearson Prentice Hall.

KULCSÁR N. (2016): A szennai hurkafesztivál sikertörténete. In: Jászberényi M. - Zátori A. - Ásványi K. (szerk.): Fesztiválturizmus. Akadémiai Kiadó, Budapest. pp. 227-233.

LAPIERRE, J. (2000): Customer-Perceived Value in Industrial Contexts. The Journal of Business \& Industrial Marketing. 15(2-3). pp. 122-140.

NEULINGER Á. (2016): Több-módszertanú és vegyes módszertanú kutatások. Vezetéstudomány. 47(4). Marketingtudományi különszám. pp. 63-66.

PARASURAMAN, A. - GREWAL, D. (2000): The Impact of Technology on the Quality- ValueLoyalty Chain: A Research Agenda. Journal of the Academy of Marketing Science. 28(1). pp. 168-174.

PARASURAMAN, A. - ZEITHAML, V. A. BERRY, L. L. (1985): SERVQUAL: A Conceptual Model of Service Quality and Its Implications for Future Research. Journal of Marketing. 49(4). pp. 41-50.
SALDANA, J. (2015): The Coding Manual for Qualitative Researchers. $3^{\text {rd }}$ edition. Sage Publications Ltd.

SÁNCHEZ-FERNÁNDEZ， R. - INIESTABONILLO, M. Á. (2007): The concept of perceived value: a systematic review of the research. Marketing Theory. 7(4). pp. 427-451.

SCHMITT, B. H. (2003): Customer Experience Management - A revolutionary approach to connecting with your customers. John Wiley \& Sons, New Jersey.

SCHULTZ, D. E. (2003): Evolving Marketing and Marketing Communication into the $21^{\text {st }}$ Century. In: Iacobucci, D. - Calder, B. (eds): Kellogg on Integrated Marketing. John Wiley \& Sons, New Jersey. Foreword.

SULYOK J. - SZIVA I. (2009): A fesztiválturizmus nemzetközi és hazai tendenciái. Turizmus Bulletin. 13(3). pp. 3-13.

WOODRUFF, R. B. (1997): Customer Value: The Next Source for Competitive Advantage. Journal of the Academy of Marketing Science. 25(2). pp. 139-153.

YUAN, Y-H. E. - WU, C. K. (2008): Relationships Among Experiential Marketing, Experiential Value, and Customer Satisfaction. Journal of Hospitality \& Tourism Research. 32(3). pp. 387410.

ZEITHAML, V. A. (1988): Consumer perceptions of price, quality, and value: a means-end model and synthesis of evidence. Journal of Marketing. 52(3). pp. 2-22.

WALTERS, D. (2002): Operations strategy. PalgraveMacMillan, New York.

\section{Internetes források}

SZABÓ J. Z. (2015): Milliók szórakozása - Hová tart a magyar fesztiválpiac? http://www.portfolio.hu/ gazdasag/milliok_szorakozasa_hova_tart_a_ magyar_fesztivalpiac.208528.html, Letöltve: 2017. március 10. 